\title{
The Impact of Competition Policy on the National Economy of a Country with a Developing Culture of Competition
}

\author{
Irena Pekarskiene, Jurgita Bruneckiene, Rasa Daugeliene, Lina Peleckiene
}

\author{
Kaunas University of Technology \\ K. Donelaicio st. 73, LT-44029, Kaunas, Lithuania \\ E-mail.irena.pekarskiene@ktu.lt, jurgita.bruneckiene@ktu.lt,rasa.daugeliene@ktu.lt,peleckiene.lina@gmail.com
}

cross $^{\text {ref }}$ http://dx.doi.org/10.5755/j01.ee.29.1.18905

\begin{abstract}
The article provides a theoretical and empirical analysis of the impact of competition policy on the national economy of a country with a developing culture of competition, through the effects of competition policy and the impact of deterrence of sanctions for breaches of competition. The theoretical analysis has revealed a positive relationship between a successful implementation of competition policy and the country's economic development. The article reviews the situation related to the implementation of competition policy in countries with developing/emerging culture of competition - Lithuania and Latvia. Quantitative research has shown that competition policy in countries with a developing/emerging culture of competition is mostly manifested through the same areas as in countries with a developed competition culture: the areas of innovation, investment, international trade and human resources. Qualitative research has shown that there is a positive tendency within countries with a developing/emerging culture of competition that more and more economic entities are ready to compete fairly, and the competition itself is considered as a value. In addition, while the deterrence from violations of competition law in countries with a developing/emerging competition culture is lower than in countries with a developed competition culture, the impact of an effective competition policy on the reduction of and deterrence from the intentions to violate competition is apparent.
\end{abstract}

Keywords: Competition Policy; Economic Growth; Deterrence; a Country with a Developing Culture of Competition.

\section{Introduction}

The main objective of competition policy, as set out in both the EU, national legal documents and in the scientific literature, is to protect freedom of competition and establish conditions for competition, in order to ensure an effective and fair competition between economic entities, which would bring the biggest potential benefit to consumers. The implementation of competition policy increases competitiveness of enterprises and ensures an optimal use of resources and the highest degree of social welfare, which are the basic conditions for ensuring economic growth. Although sometimes competition policy is criticized by free market advocates, but recent research acknowledges the importance of competition policy for the economy.

Competition must (should) be protected and valued because there is a link between competition and economic welfare and development, not only in the short but also in the long period. The links between competition policy and the country's economic growth have been researched by scientists by focusing the research on both the competitiveness of the country or industry and on separate components of economic growth. Scientists have proved by their work not only the existence of a strong link between the effectiveness of competition policy and economic growth, and that the implementation of supervision of competition positively effects GDP per capita, competition policy promotes social welfare and encourages companies to abandon anti-competitive behaviour without the interference of competition supervisory authorities, but also that competition policy in the times of crisis has had a positive impact on economic growth, which is especially important for countries with a higher economic vulnerability. Consequently, exploring the problem issues of implementation of competition policy becomes not only a relevant, but also a timely issue in small economy countries.

While analysing the impact of competition policy on the economy, researchers mostly addressed the issue in three aspects: through the relationship between competition policy and the economy, the effect of violation of competition (often the damage) on national economy and the effect of sanctions for violations of competition. Most frequently, the researchers are focusing on such breaches of competition as cartel agreements, the abuse of a dominant position, prohibited mergers, misleading advertising and other anti-competitive practices. Their impact on the national economy is more extensively analyzed not only in the works of foreign researchers (Maier-Rigaud \& Schwalbe, 2013; Marshall \& Marx, 2012; Utton, 2011; Gunster et al., 2011; Khimich et al., 2011; Van Bergeijk, 2009; Bertrand \& Ivaldi, 2006; Levenstein \& Suslow, 2004; Hinloopen \& Normann, 2009; Mackendrot \& Gallego, 2008; Doytch \& Cakan, 2011; DePhamphilis, 2014; Doytch \& Uctum, 2011), but also in the works of Lithuanian researchers (Bruneckiene et al., 2015, Pekarskiene \& Bruneckiene, 2015, Bruneckiene \& Pekarskiene, 2015; Stanikunas, 2009, Novosad \& Moisejevas, 2012; Klimasauskiene, 2006) that include case studies of both the countries with a developed culture of competition and countries with a developing/emerging culture of competition. The researchers' works have shown that the economic environment of countries with a developing/ emerging 
competition culture, poor supervision of competition or its absence creates favourable conditions for violating competition, and the damage caused by these violations is much higher than that in the markets of a developed competition culture, and does not encourage economic growth. Given that these issues have been extensively explored by both foreign and Lithuanian scientists, their aspects will not be addressed in this article. Studies on the sanctions for violations of competition have received a sufficient attention among researchers as well. In today's world, much effort is made to increase the deterrent nature of sanctions; nevertheless, there is still a lot of criticism found in the scientific literature due to the lack of their deterrence. Both theoretical and empirical works of the researchers (London Economics, 2011; Chang \& Harrington, 2010; Huschelrath \& Weigand, 2010; Huschelrath, 2009; Lande \& Davis, 2008; Rogers, 2005; Miller, 2009) prove that the sanction itself, as well as other measures (the possibility of imprisonment, the system of exemption from fines, etc.) directly affect the deterrence from unlawful actions by breaching competition. Although there is a lack of empirical research at the European Union level, however, the researchers' questionnaire surveys and expert studies (the assessment of the Competition Council's of the Republic of Lithuania operational activities in 2014 - 2016, London Economics, 2011; OFT, 2007) showed that each disclosed act of infringement of competition law reduces the incentives to breach on average by 4 - 7 times, depending on the nature of the infringement. It should be noted that the effect of sanctions for violations of competition has not been explored by researchers so far; therefore, for the analysis on the impact of violations of competition on the economy the studies conducted by foreign researchers are referred to. However, in different economies with a different level of the competition culture development, the effects of deterrence from violations of competition differ; therefore it is important to examine the deterrent effect of sanctions for violations of competition in the country with a developing/emerging culture of competition. Studies on the impact of competition policy on the economy have also been conducted exclusively by foreign researchers (Buccirossi et al. 2011; Sama, 2013; Romano, 2015; Gutmann \& Voigt, 2014; Lande \& Connor, 2005; Mosteanu \& Romano, 2013; Gunster et al., 2011; Buccirossi et al., 2013; Marshall \& Marx, 2012; Petersen, 2013; Borrell \& Tolosa, 2008). In the works of Lithuanian authors, this problem has hardly been ever addressed, only some fragmentary research within the general context of legal regulation of competition has been carried out (Ginevicius \& Krivka, 2009; Stanikunas, 2009; Novosad \& Moisejevas, 2012; Klimasauskiene, 2006).

The research problem. The impact of competition policy on the economy is not a new theme, but the main focus of research on this issue was based on the practices of developed countries where the implementation of competition policy has a long history and the society has developed a competition culture and competition supervision practice, while there is a lack of case studies based on the practice of countries with a developing/emerging competition culture. Given the fact that the effectiveness of competition policy is closely linked to the experience of the competition authority and the size of the economy, it is relevant to analyse the impact (direct and indirect) of competition policy on a small economy country with the developing culture of competition. Only knowing the impact areas of competition policy and the impact itself, within the context of the specifics of the economies of countries with a developing competition culture, it is possible to develop effective measures for the implementation of competition policy.

The aim of the article is to assess the impact of competition policy on the economy of a country with a developing culture of competition through the impact areas of competition policy and the deterrent effect of sanctions for violations of competition.

\section{Literature Analysis}

The principles of competition policy in the United States were laid down by the Sherman Act (1890), the Cleiton Act (1914), and the Federal Trade Commission Act. Whereas in Europe, the competition policy began to develop after the Second World War, when, in 1957, in order to encourage the development and integration of national markets, on March 25, 1957, a European Community (EC) Treaty was signed in Rome, which highlights a strong commitment to fair competition. It should be noted that during the period of 1890 - 1990 only a few countries pursued competition policy, but since 1990, radical changes took place, when countries started massively to implement measures of competition policy - currently, more than 100 countries are applying competition policy (Gutmann \& Voigt, 2014).

In order to find an answer to the question why some countries are richer then others, the McKinsey Global Institute has explored the development of 13 countries in the world (including the USA, UK, France, Germany, Japan, India, Brazil, Korea, Russia, Poland, Sweden, Australia) within the period of 12 years. The answer to this question is a different level of productivity in these countries. The study covered the analysis of potential factors of productivity: labour productivity, capital formation, corporate governance, education, competition and found that a key factor that affects productivity levels is the protection of free competition. The authors of the study (Manyika et al., 2015) emphasize that the economic progress depends on increased productivity, which, in turn, depends on unconstrained competition.

Different scholars interpret and describe the essence of competition policy in different ways. Motta (2004) describes competition policy as a set of beliefs and laws that guarantee that competition in the market is not restricted, and at the same time the economic welfare is not reduced. According to Jones \& Sufra (2004), competition policy involves measures by which the government encourages competitive market structures and behaviour. Eekhoff \& Moch (2004) argue that competition policy is designed to prevent companies from acting against their competitors and exploit the consumers and taxpayers. Jones \& Sufra (2004) describes competition policy as a way to promote and develop fair competition. Despite different descriptions of competition policy, the core of the state's competition policy is to ensure "healthy" competition in the market, in compliance with specific established rules, regulations, substatutory legal acts which prohibit the pursuit of economic benefit by monopolizing markets, abusing the market position, concluding illegal agreements between competitors or otherwise violating competition. 
The issues of the impact of competition policy on the national economy have recently attracted an increased researchers' attention. The European Commission (2016) provided an explanation that fair competition occurs as a result of competition policy; and, consequently, the entrepreneurship and efficiency are promoted and consumers receive direct benefits, as an efficient production and competition between companies lead to producing more and better quality and cheaper products, and a larger range of products is available on the market. Competition in the market encourages innovation - companies emerge that are striving to produce better products - they are innovative in product development, in the project implementation, introduction of production processes, etc. In addition, competitive enterprises not only promote national economy, but by entering the global markets, also contribute to the development of international economy. Referring to the intensity of competition, Nickell (1996) focused his research on specific industries, in order to find out why some industries are developing faster than others. Studies have shown that the market concentration has a negative impact on productivity, while industries with higher competition have been forced to increase the efficiency of companies, thus making them more competitive and more attractive to the consumer. Stanikunas (2009) argued that the implementation of competition policy in the market increases competition, which increases consumer welfare and encourages economic growth. Dutz \& Hayri (1999), Dutz \& Vagliasindi (2000), while evaluating the efficiency of different competition policy regimes of 18 countries by three criteria (i.e. ensuring operation, protection of competition and institutional efficiency), found that there is a positive correlation between the efficiency of competition policy and economic growth. Porter (2000) empirically estimated and provided evidence that the intensity of competition and antitrust policy have a positive correlation with the growth of GDP per capita. While analysing the data of 22 different sectors of 12 European Community countries within the period of 1995-2005, Buccirossi et al. (2011) found that competition policy has a positive impact on productivity. Petersen (2013) found that the adoption of competition laws and the implementation of their supervision in the long term perspective have a positive impact on the GDP per capita and on the rate of economic growth. Mosteanu \& Romano (2013) explored how competition policy was functioning in the European Union during the crisis. The study used the data of 27 countries over a five years period, and the analysis was based on each country's GDP per capita and the global competition index. The results confirmed that during the crisis competition policy had a positive impact on economic growth, which is particularly important for the countries with a higher economic vulnerability. The scholars (Gunster et al., 2011; Maier-Rigaud \& Schwalbe, 2013; Utton, 2011; Marshall \& Marx, 2012) who examined the consequences of one of the most harmful violations of competition - cartels emphasized that productivity suffers from the existence of cartels, as cartel companies are deprived of incentives for introducing technologies and producing at the lowest cost, which leads to inefficiencies in productivity in a relevant industry. Lack of innovation has a direct impact on the quality of products, their long-term diversity and on the decrease in productivity of businesses. Although the studies are designed to assess the impact of cartels, they indirectly indicate that ensuring competition through competition policy positively impacts productivity and economic growth. In addition, according to the researchers (Khimich et al., 2011, Van Bergeijk, 2009, Bertrand \& Ivaldi, 2006, Levenstein \& Suslow, 2004), the countries' economic environment itself creates conditions for cartels to emerge: due to the lack of labour force resources and competence, in many developing countries the activities of competition supervisory authorities are not sufficiently developed, which significantly reduces the likelihood of the disclosure and punishment of cartels. This proves once again the importance of competition policy not only at the national but also international level. Thus, the effective implementation of competition policy through the interaction of competition enforcement authorities with other economic policy-making institutions ensures competition in the market and increases the productivity of economic sectors, which has a positive effect on the country's economic growth.

Due to the existing link between competition in the market, the effectiveness of competition policy and economic growth, the European Commission combats anticompetitive behaviour (particularly focusing on prohibited agreements), considers mergers and the state aid, and encourages liberalization. Therefore, those economic entities which breach the principles of fair competition are fined. For example, in 2016 fines imposed (adjusted for Court judgments) for cartels in the EU amounted to 3726 976000 EUR. The maximum fines imposed on the company since 1969 amounted to 1008766000 EUR (Daimler) and 752679000 EUR (DAF) for a cartel agreement in the Truck case. Despite such huge amounts paid to national budgets, the scientific literature (Allain et al., 2011; Utton, 2011; Bolotova \& Connor, 2008; Connor, 2008; Connor \& Lande, 2008) emphasizes that the essence of contemporary fines should be reformed from restitutive or compensational to dissuasive or deterrent. In modern world, major efforts are made to increase the deterrent nature of sanctions, but there is still a lot of criticism found in the scientific literature addressing a low level of deterrence. Both theoretical and empirical findings identified by the researchers (Bruneckiene et al., 2015; Chang \& Harrington, 2010; Huschelrath \& Weigand, 2010; Huschelrath, 2009; Lande \& Davis, 2008; Rogers, 2005; Miller, 2009) prove that the fine itself, like other measures (possibility of imprisonment, the system of exemption from fines, etc.) directly affects deterrence from unlawful acts. Although there is a lack of empirical research across the European Union, however, based on the assessment on the deterrence of sanctions conducted by the London Economics (2011), in the European Union, the most deterrent are the financial penalties for companies, while in the USA - the Effective Leniency Program, Extra Deterrence from Private Actions and Penalties on individuals (incarceration). The researchers' questionnaire surveys and expert studies (the evaluation of the effectiveness of operational activities of the Competition Council of the Republic of Lithuania within 2014-2016, London Economics, 2011; OFT, 2007) showed that each identified breach of competition law reduces the incentives to breach on average by 4-7 times, depending on the nature of the breach (conservative evaluation). In the cases of 
cartels and unannounced and implemented concentrations restricting competition, a single cartel disclosed or a fine imposed for such a competition-restricting unlawful concentration deters from creating 5 other cartel or mergers restricting competition, and each disclosed case of abuse of a dominant position deters from 4 other competitionrestricting actions of economic entities that hold a dominant holdings position. According to the data of the entrepreneurs' survey, this ratio is much higher. For example, according to the survey, one case of a competition-restricting agreement, disclosed by the competition supervisory authority deters from the creation / maintenance of 16 other cartels. The London Economics (2011) study showed that the deterrence is significantly higher: from 12 times the abuse of a dominant position to 28 times of cartel cases. The survey of major advertising agencies has shown that one of the Competition Council's decisions on misleading or inadmissible comparative advertising deters from 3 similar advertisements in the future. Although information sources provide very different evaluations, but a conservative evaluation (4-7 times) of these indicators, and assuming that all violations of competition would have caused similar damage, it is possible to conclude that sanctions carry a significant deterrence and create additional benefits for the entire economy. There is a lack of research on the differences in deterrence from breaches of competition in countries with different levels of competition culture. In the majority of cases, researchers from countries with a low competition culture, while analysing the impact of competition violations on the economy, use the results of research of a highly developed competition culture. As the deterrence differs within countries with a different level of development of the competition culture, this issue should receive more attention from researchers. Only after identifying the deterrence characteristic to a particular country, it is possible to develop an effective competition policy.

Summarizing the research of different authors, it can be noted that the effective implementation of competition policy ensures competition in the market, which has a positive impact not only on companies and consumers, but also on the entire national economy. When assessing the impact of competition policy on a macro level, it is necessary to distinguish not only the direct effect that results from the disclosure and suppression of violations of competition, but also the indirect effect, i.e. deterrence, which is manifested by the fact that economic entities are deterred from possible similar violations of competition.

\section{Current Situation Analysis in Lithuania and Latvia}

Both in Lithuania and Latvia the implementation of competition policy covers less than two decades, so it is possible to say that the competition culture in these countries is emerging in comparison with the old EU countries. After Lithuania regained the Independence in 1990, the Constitution of the Republic of Lithuania issued a statement that it is prohibited to monopolize the markets and production, and the law protects the freedom of fair competition. The first Law on Competition in Lithuania was adopted in 1992; the law was based on the model of the US competition law. When Lithuania declared its determination to integrate into the European Union in 1999, the Law on Competition was replaced by a new version, which reflected the model of the European Union Competition Law. The current Lithuania's Law on Competition actually complies with the EU Competition Law and the requirements of the competition law applicable in the other EU Member States. The Competition Council, as an independent competition supervisory authority, started its activities in 1999. A similar situation was also in neighbouring Latvia - the Law on Competition was adopted in 1991, and in 1998 a new version of the Law on Competition came into force, in line with the EU Competition Law, and in the same year Latvia's Competition Council was established.

After analysing the identified cases of violations of competition over the period of 2005-2015 (see Figure 1), we see that the number of the identified breaches of competition is similar in both countries: in Lithuania - 170 breaches, in Latvia - 156 breaches during the analysed period.

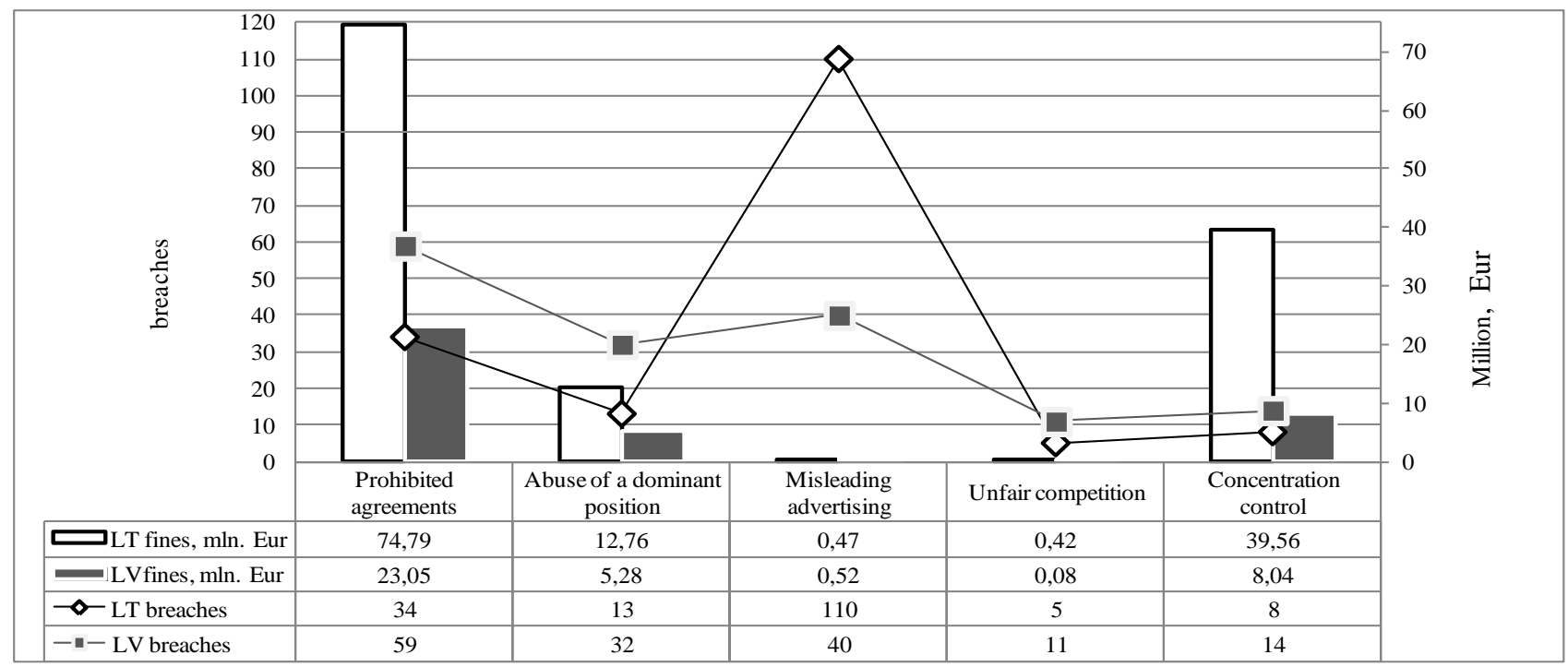

Figure 1. Identified Breaches of Competition Law and Fines Imposed in Lithuania and Latvia over the Period of 2005-2015 
The structure of violations is slightly different: in Lithuania, the majority of violations are detected in the field of misleading and comparative advertising (64\%), in the second place - in the area of prohibited agreements $(20 \%)$, other violations amount up to $10 \%$. Meanwhile in Latvia, the highest number of breaches was detected in the area of prohibited agreements $(37.8 \%)$, misleading and comparative advertising $25.6 \%$ and abuse of a dominant position - 20.5 $\%$. During the period reviewed, fines amounting to nearly 128 million EUR were imposed for the breaches of competition in Lithuania; in Latvia - almost 37 million EUR, i.e. 3.4 times less than in Lithuania. The fact that in both countries the majority of fines are imposed for prohibited agreements confirms theoretical statements about the seriousness of these violations for competition and the national economy. It only proves that it is important for the countries with a developing competition culture to strengthen competition policy in order to strengthen the entire economy and ensure its development.

According to the Global Competition Review (2015), both Competition Councils of Lithuania and Latvia are rated as "good", i.e. three stars out of five. This shows that, although competition supervision in both countries has little experience, the activities of competition supervisory authorities are sufficiently effective. Aydin (2012) believes that the effectiveness of competition policies in Lithuania is rated by 3.6 points, in Latvia - by 4 (maximum score is 7). Such an evaluation suggests that the implementation of competition policy in the countries reviewed is sufficiently effective.

The implementation capacity of competition policy depends directly on the supervisory authorities' available budget, where the main revenue includes state appropriations. In Lithuania, on average 1.23 million EUR have been allocated annually to the Competition Council, whereas in Latvia - 0.85 million EUR; however, with regard to the number of employees, the ratio of appropriations to the staff in both countries is very similar - on average, over 18 thousand EUR (see Table 1). Therefore it suggests that the financial strength of competition supervisory authorities of the countries reviewed is similar.

Table 1

Number of Lithuania's and Latvia's Competition Council Employees and State Appropriations Over the Period of 2005-2015

\begin{tabular}{|c|c|c|c|c|c|c|}
\hline \multirow[b]{2}{*}{ Year } & \multicolumn{3}{|c|}{ Lithuania } & \multicolumn{3}{|c|}{ Latvia } \\
\hline & $\begin{array}{l}\text { Appropriation in } \\
\text { total, mln. EUR }\end{array}$ & $\begin{array}{c}\text { Average } \\
\text { number of } \\
\text { employees }\end{array}$ & $\begin{array}{l}\text { Appropriation and staff ratio, } \\
\text { thousand EUR/1 employee }\end{array}$ & $\begin{array}{l}\text { Appropriation in } \\
\text { total, mln. EUR }\end{array}$ & $\begin{array}{c}\text { Average } \\
\text { number of } \\
\text { employees }\end{array}$ & $\begin{array}{l}\text { Appropriation and staff } \\
\text { ratio, thousand EUR/1 } \\
\text { employee }\end{array}$ \\
\hline 2005 & 1,05 & 62 & 16,94 & 0,72 & 46 & 15,65 \\
\hline 2006 & 1,19 & 62 & 19,19 & 0,94 & 48 & 19,58 \\
\hline 2007 & 1,16 & 62 & 18,71 & 0,98 & 52 & 18,85 \\
\hline 2008 & 1,33 & 63 & 21,11 & 1,05 & 55 & 19,09 \\
\hline 2009 & 1,05 & 62 & 16,94 & 0,87 & 46 & 18,91 \\
\hline 2010 & 0,87 & 60 & 14,50 & 0,44 & 43 & 10,23 \\
\hline 2011 & 1,01 & 66 & 15,30 & 0,58 & 34 & 17,06 \\
\hline 2012 & 1,28 & 72 & 17,78 & 0,82 & 45 & 18,22 \\
\hline 2013 & 1,29 & 71 & 18,17 & 0,83 & 45 & 18,44 \\
\hline 2014 & 1,61 & 71 & 22,68 & 1,06 & 49 & 21,63 \\
\hline 2015 & 1,69 & 72 & 23,47 & 1,08 & 46 & 23,48 \\
\hline Average & 1,23 & 65 & 18,62 & $\mathbf{0 , 8 5}$ & 46 & 18,29 \\
\hline
\end{tabular}

Over the period reviewed, the Lithuanian Government allocated 13.53 million EUR to the Competition Council; while the fines imposed by the Competition Council for the detected violations of competition amounted to 128 million EUR, i.e. 9.5 times more than the funding received. In Latvia, 9.37 million EUR were allocated to the Competition Council from the budget, and the fines imposed amounted to 37 million EUR, i.e. 3.9 times more than the funding received. The financing of competition supervisory institutions directly affects their operational activities - with more funding available, institutions would be able to carry out more investigations related to the breaches of competition law, hire experts from relevant fields, and this would help them to make more accurate and time consuming decisions on violations of competition in various areas. It should also be noted that the decision of the Competition Council on imposing fines and the payment of fines to the budget takes a considerable amount of time, because in most cases there is a judicial process going on, in which the amount of fines can be reduced and, in individual cases, fines are cancelled, e. g. in 2011, the Supreme Administrative Court of Lithuania annulled the fine imposed on the $\mathrm{AB}$ "Rokiskio suris" and UAB "Marijampoles pieno konservai"; in 2014 - on the AB "Seb bankas", AB "Swedbank", AB "DnB bankas". Despite the fact that not all fines imposed for violations of competition are paid, the conducted or initiated investigations for alleged breaches of the Law on Competition are a serious warning to other economic entities not to start anti-competitive activities.

In pursuit to evaluate the effect of their operational activities, the Competition Councils, following the methodology recommended by the OECD, assesses the benefits of their activities to consumers. The assessment involves the direct benefits to consumers and indirect benefits from fines and deterrence from similar violations. According to the data of the competition supervisory authorities of Lithuania and Latvia, the benefits (direct and indirect) to consumers over the period of 2008-2015 each year, on average, amounted to: in Lithuania - about 61.63 million EUR and exceeded the state appropriations by 6 times; in Latvia 51 million EUR and exceeded the state appropriations by 7 times. This allows assuming that 1 EUR invested in the supervision of competition by the state brings the benefit of 6 EUR to the consumer in Lithuania; and 7 EUR to the consumer in Latvia. All this supports the assumption that the 
state funds spent on monitoring competition make a significant contribution to the overall national welfare.

\section{Methodology}

The assessment on the impact of competition policy on the economy in the case of a country with a developing culture of competition involves quantitative and qualitative research. Quantitative research will focus on analysing and assessing the impact of competition policy on the economy through its areas of operation. Qualitative research will address and assess the impact on the economy through the deterrence of sanctions for violations of competition. Quantitative research is conducted in the following logic: based on the scientific literature, the areas of manifestation of the impact of competition policy are identified and their characteristic indicators, i.e. the areas and indicators through which competition policy impacts (manifests itself in) the economy. Subsequently, based on the scientific literature, the indicators have been selected that reflect the impact of competition policy (result) and, simultaneously, the economic status of the country (see Table 2). Taking into account the wide range of impact areas of the competition policy, covering both the economic, social and political aspects, table 2 includes the identified main areas of impact of competition policy, mostly related to the economy and available for the quantitative evaluation. The authors of this article believe that the operational capacity of the competition supervisory authorities is directly related to the funding received (state appropriations) (Grants), and this affects the implementation of competition policy; therefore, the state appropriations allocated to the competition supervisor authority is included into the study as an additional indicator of the impact of the competition policy.

Indicators Used in the Empirical Research

Table 2

\begin{tabular}{|c|c|c|c|c|}
\hline $\begin{array}{c}\text { Areas of the } \\
\text { manifestation of the } \\
\text { impact of competition } \\
\text { policy (reason) }\end{array}$ & $\begin{array}{l}\text { Indicators } \\
\text { reflecting the } \\
\text { areas }\end{array}$ & $\begin{array}{c}\text { Authors who used the } \\
\text { indicators for empirical } \\
\text { research and theoretical } \\
\text { analysis }\end{array}$ & $\begin{array}{l}\text { Indicators reflecting } \\
\text { the impact of } \\
\text { competition policy } \\
\text { (consequence) }\end{array}$ & $\begin{array}{l}\text { Authors who used the } \\
\text { indicators for empirical } \\
\text { research and theoretical } \\
\text { analysis }\end{array}$ \\
\hline Investment & $\begin{array}{l}\text { Gross capital } \\
\text { formation }(\% \text { of } \\
\text { GDP) }\end{array}$ & $\begin{array}{l}\text { Buccirossi et al. (2013); Sama } \\
\text { (2013); Romano (2015); } \\
\text { Gutmann \& Voigt (2014), }\end{array}$ & $\begin{array}{l}\text { Value added of labor } \\
\text { productivity/1 } \\
\text { working hour }\end{array}$ & $\begin{array}{l}\text { Mosteanu \& Romano (2013), } \\
\text { Gunster et al. (2011)., } \\
\text { Buccirossi et al. (2013), } \\
\text { Marshall \& Marx (2012), Ma } \\
(2011)\end{array}$ \\
\hline Innovation & $\begin{array}{l}\text { R\&D } \\
\text { GDP })\end{array} \quad\left(\begin{array}{l}\% \\
\end{array}\right.$ & $\begin{array}{l}\text { Nickel (1996); Buccirossi } \\
\text { et al. (2013); Sama (2013); } \\
\text { Romano (2015); Bruneckiene } \\
\text { et al. (2015) }\end{array}$ & GDP & $\begin{array}{l}\text { Nickel (1996); Buccirossi } \\
\text { (2009); Petersen (2013); Sama } \\
\text { (2013); Romano (2015); } \\
\text { Pekarskiene \& Bruneckiene } \\
\text { (2015) }\end{array}$ \\
\hline International trade & $\begin{array}{l}\text { Trade openess } \\
(\% \text { of GDP) }\end{array}$ & $\begin{array}{l}\text { Buccirossi et al. (2013); } \\
\text { Romano (2015); Bruneckiene } \\
\text { et al. (2015), Lande \& } \\
\text { Connor, 2005 }\end{array}$ & GDP per capita & $\begin{array}{l}\text { Nickel (1996); Porter (2000); } \\
\text { Buccirossi (2009); Sama } \\
\text { (2013); Romano (2015); }\end{array}$ \\
\hline Investment & $\begin{array}{l}\text { Investment } \quad(\% \\
\text { of GDP })\end{array}$ & $\begin{array}{l}\text { Nickel (1996); Bruneckiene } \\
\text { et al. (2015), Gutmann \& } \\
\text { Voigt (2014), }\end{array}$ & $\begin{array}{l}\text { Consumer price index, } \\
\text { CPI }\end{array}$ & $\begin{array}{l}\text { Buccirossi et al. (2013); Sama } \\
\text { (2013); Romano (2015); }\end{array}$ \\
\hline \multirow{3}{*}{ Human resources } & $\begin{array}{l}\text { Unemployment } \\
\text { rate, \% }\end{array}$ & Nickel (1996); & $\begin{array}{l}\text { Industry price index, } \\
\text { IPI }\end{array}$ & $\begin{array}{l}\text { Nickel (1996); Bruneckiene } \\
\text { et al. (2015) }\end{array}$ \\
\hline & \multirow{2}{*}{$\begin{array}{l}\text { Human Social } \\
\text { Development } \\
\text { Index, HDI }\end{array}$} & \multirow[b]{2}{*}{$\begin{array}{l}\text { Baker (2003), Werden (2003), } \\
\text { Gutmann \& Voigt (2014) }\end{array}$} & $\begin{array}{l}\text { Economic } \\
\text { index, } \%\end{array}$ & $\begin{array}{l}\text { Baker (2003), Werden (2003), } \\
\text { Stanikunas (2009) }\end{array}$ \\
\hline & & & $\begin{array}{l}\text { General } \\
\text { competitivness index, } \\
\text { GCI }\end{array}$ & $\begin{array}{l}\text { Baker (2003), Werden (2003), } \\
\text { Borrell \&Tolosa (2008), } \\
\text { Bruneckiene } \text { et al. } \text { (2015) }\end{array}$ \\
\hline $\begin{array}{l}\text { Financial capacity of } \\
\text { competition } \\
\text { supervisory } \\
\text { institutions }\end{array}$ & $\begin{array}{l}\text { Appropriation to } \\
\text { the competition } \\
\text { supervisory } \\
\text { authority }\end{array}$ & & & \\
\hline
\end{tabular}

For the assessment of the impact of competition policy on the national economy, a correlation analysis is conducted. As the variables used in the study are interval in nature, so before conducting the correlation analysis, we check whether the tested variables are distributed by the normal distribution. For this purpose, a normal distribution check is carried out by the Kolmogorov - Smirnov and Shapiro - Wilk test. The analysed distribution from the normal distribution is expressed through the obtained sig. value If sig. value is $\geq 0,05$, then the analysed distribution is distributed by the normal distribution, but if sig. value is $<$ 0,05 , then the analysed distribution is not distributed according to the normal distribution. In the cases where the analysed distribution is not distributed by the normal distribution, it is subjected to a functional change. Functional replacement is performed through arithmetic operations - logarithming, squaring, etc. After performing a functional change test, the normal distribution is verified by the Kolmogorov-Smirnov and Shapiro-Wilk test.

After determining that the data used in the study are distributed according to the normal distribution, correlation analysis can be applied to determine the strength of relationship between the selected variables. For validation of the significance of the correlation coefficient the 
Student's criterion is used, with a reliable error of not more than 0.05 .

Two countries with a developing competition culture Lithuania and Latvia - have been chosen for conducting quantitative research. In Lithuania, the Competition Council has been providing official information since 1999, while the Latvian Competition Council has been providing information since 2005, which has determined the selection of the investigation period (2005-2016). The study uses statistical data published by the Competition Councils and Statistical Departments of Lithuania and Latvia.

In order to determine the deterrent effect of sanctions on violations of competition in the country with a developing culture of competition, a qualitative research is carried out, based on the case of Lithuania. 89 economic entities from all over Lithuania were interviewed in an empirical study: $82 \%$. of respondents represented enterprises, $18 \%$ - entities of the public sector (municipal administrations (6\%), budget institutions (12\%)). Empirical research involved companies from the following Lithuanian sectors, where, according to researchers and reports (Pekarskiene \& Bruneckiene, 2015, Dorabialski, 2014, Grout \& Sonderegger, 2005, the Competition Council's of the Republic of Lithuania working reports), the likelihood of violations of competition is greater: chemistry, book sales, leisure activities , pharmaceuticals, catering, construction, petroleum products retailing, sales of alcoholic beverages, food products, plastic manufacturing, telecommunications, consulting and auditing, flour, cargo services, travel agency services, insurance, driver training services, taxi services, paper, milk purchasing and processing market, advertising and media planning services, event organisation services, waste handling, utilisation and processing, production and trading in audio-visual articles, sale of decoupage, needlework and other related goods, production of orthopaedic articles, ship agency and other shipping services, cash collection and handling services, bank sector, car repairs, etc. Questionnaire feedback - $68 \%$. The survey was conducted by interviewing respondents by e-mail, telephone, orally. The survey was held in December 2016 - May 2017. The questionnaire was structured in such a way that, when answering the question, the required specific information rather than a personal opinion is provided. The majority of the survey participants included lawyers, economists and top managers from companies, organizations and institutions, who make strategic decisions

\section{Results}

In order to quantify the impact of competition policy on the economies of countries with a developing culture of competition, a correlation analysis was carried out between the indicators identified in Table 2, selected from the cause and effect perspective. While analysing Lithuania's data used in this study by Kolmogorov-Smirnov and ShapiroWilk tests, it was found that all variables were distributed according to the normal distribution (sig. values obtained for the indicators are higher than 0.05), therefore a correlation analysis was done with all the identified indicators. The testing of Latvia's data revealed that not all variables were distributed according to the normal distribution, i.e. the normal distribution assumptions was not satisfied by the consumer price index and the human development index (value less than 0.05); therefore, the functional change of the values of the above indicators was performed - squaring and checking the normal distribution of values once again. After the functional change, the sig. values obtained by applying Kolmogorov-Smirnov and Shapiro-Wilk tests, were higher than 0.05 , therefore a correlation analysis of these indicators was performed as well. After the completion of correlation analysis, only significant results (see Table 3) were selected, i.e. which satisfied the Student's criterion, at the expense of reliability of no more than 0.05 .

\section{Results of Correlation Analysis}

\begin{tabular}{|c|c|c|c|c|c|c|c|c|}
\hline & & 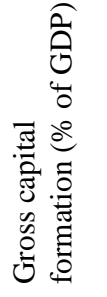 & 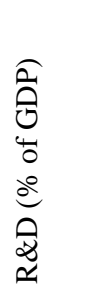 & 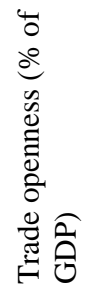 & 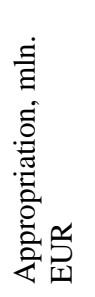 & 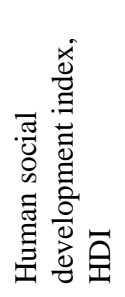 & 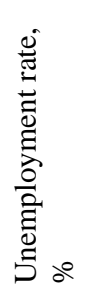 & 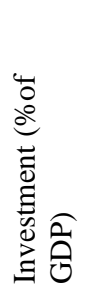 \\
\hline \multicolumn{9}{|c|}{ Lithuania } \\
\hline \multirow{2}{*}{$\begin{array}{l}\text { Labour productivity } \\
\text { Eur/hour }\end{array}$} & Pearson coef. & & $\mathbf{0 , 8 8 9}$ & $\mathbf{0 , 8 7 6}$ & & $\mathbf{0 , 9 3 7}$ & & \\
\hline & Sig. (2-tailed) & & 0,001 & 0,005 & & 0.001 & & \\
\hline \multirow{2}{*}{ GDP } & Pearson coef. & & 0,609 & 0,629 & & $\mathbf{0 , 7 7 7}$ & & \\
\hline & Sig. (2-tailed) & & 0,047 & 0,038 & & 0,005 & & \\
\hline \multirow{2}{*}{ GDP per capita } & Pearson coef. & & 0,727 & $\mathbf{0 , 7 3 5}$ & & 0,869 & & \\
\hline & Sig. (2-tailed) & & 0,011 & 0,010 & & 0,001 & & \\
\hline \multirow{2}{*}{ Consumer price index, CPI } & Pearson coef. & $-0,630$ & $\mathbf{0 , 8 0 0}$ & $\mathbf{0 , 8 0 3}$ & & 0,925 & $\mathbf{0 , 6 0 3}$ & $-0,657$ \\
\hline & Sig. (2-tailed) & 0,038 & 0,003 & 0,003 & & 0,000 & 0,050 & 0,028 \\
\hline \multirow{2}{*}{ Industry price index, IPI } & Pearson coef. & & 0,595 & 0,866 & & $\mathbf{0 , 7 3 5}$ & & \\
\hline & Sig. (2-tailed) & & 0,050 & 0,001 & & 0,010 & & \\
\hline \multirow{2}{*}{$\begin{array}{l}\text { Economic freedom index, } \\
\%\end{array}$} & Pearson coef. & & $\mathbf{0 , 8 3 1}$ & $\mathbf{0 , 5 8 8}$ & $\mathbf{0 , 8 7 9}$ & 0,708 & & \\
\hline & Sig. (2-tailed) & & 0,002 & 0,050 & 0,000 & 0,015 & & \\
\hline \multirow{2}{*}{$\begin{array}{l}\text { General competition index, } \\
\text { GCI }\end{array}$} & Pearson coef. & & & & $\mathbf{0 , 7 3 1}$ & & & \\
\hline & Sig. (2-tailed) & & & & 0,011 & & & \\
\hline
\end{tabular}




\begin{tabular}{|c|c|c|c|c|c|c|c|c|}
\hline & & 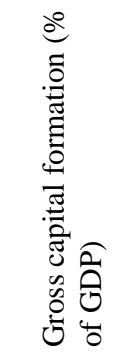 & 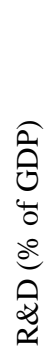 & 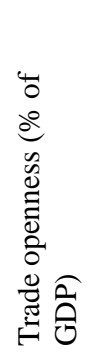 & 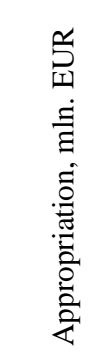 & 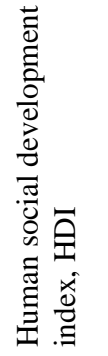 & 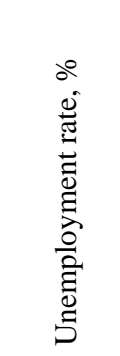 & 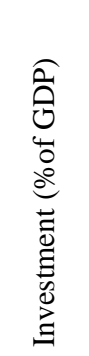 \\
\hline \multicolumn{9}{|c|}{ Latvia } \\
\hline \multirow{2}{*}{$\begin{array}{l}\text { Labour productivity, } \\
\text { Eur/hour }\end{array}$} & Pearson coef. & $\mathbf{0 , 5 8 6}$ & & & $\mathbf{0 , 7 8 1}$ & $\mathbf{0 , 5 5 9}$ & $-0,756$ & \\
\hline & Sig. (2-tailed) & 0,042 & & & 0,001 & 0,031 & 0,003 & \\
\hline \multirow{2}{*}{ GDP } & Pearson coef. & & & & & 0,630 & & \\
\hline & Sig. (2-tailed) & & & & & 0,038 & & \\
\hline \multirow{2}{*}{ GDP per capita } & Pearson coef. & & & & & 0,675 & & \\
\hline & Sig. (2-tailed) & & & & & 0,023 & & \\
\hline \multirow{2}{*}{ Consumer price index, $\mathrm{CPI}$} & Pearson coef. & $-0,751$ & & 0,618 & & & & $-0,748$ \\
\hline & Sig. (2-tailed) & 0,008 & & 0,043 & & & & 0,008 \\
\hline \multirow{2}{*}{ Industry price index, IPI } & Pearson coef. & $-0,611$ & & 0,621 & & 0,656 & & $-0,607$ \\
\hline & Sig. (2-tailed) & 0,046 & & 0,041 & & 0,029 & & 0,048 \\
\hline \multirow{2}{*}{$\begin{array}{l}\text { Economic freedom index, } \\
\%\end{array}$} & Pearson coef. & & & & & $\mathbf{0 , 8 3 2}$ & & \\
\hline & Sig. (2-tailed) & & & & & 0,001 & & \\
\hline \multirow{2}{*}{$\begin{array}{l}\text { General competition index, } \\
\text { GCI }\end{array}$} & Pearson coef. & & & & & & $-0,728$ & \\
\hline & Sig. (2-tailed) & & & & & & 0,011 & \\
\hline
\end{tabular}

In the case of Lithuania, 23 significant correlation relationships were identified between the indicators of the impact of competition policy distribution and indicators reflecting the impact. In Lithuania, the impact of competition policy on the economy is mostly manifested through $\mathrm{R} \& \mathrm{D}$, trade openness and the human development index, and the indicators mostly subjected to the impact include the labour productivity, GDP, GDP per capita, consumer price index, industrial price index and economic freedom index. It should be noted that in the case of Lithuania, in contrast to Latvia, the relationship between all indicators reflecting the impact of the competition policy distribution and the indicators that reflect the impact of competition policy on the economy has been identified. Meanwhile, in the case of Latvia, no significant correlation between the $\mathrm{R} \& \mathrm{D}$ and impact indicators was established. In the case of Latvia, 15 significant correlation relationships were identified between the indicators of the impact of the competition policy distribution and indicators reflecting the impact. The impact of competition policy on the economy is mostly manifested through the human development index and gross capital formation, and the indicators mostly subjected the impact include: the labour productivity, consumer price index, industry price index. The obtained results show that the implementation of competition policy encourages competition in the market, therefore, in order to maintain competitiveness economic entities must increase investment, introduce innovation, launch new products, which leads to the increase in labour productivity and reduction in the price level.

The results obtained from the correlation analysis, based on the examples of both countries, confirm the theoretical statements that competition policy has a positive impact on the country's economic growth. Empirical research has shown that competition policy in the countries with a developing competition culture is mostly manifested through the same areas as in the case of countries with a developed competition culture: innovation, investment, international trade and human resources, i.e. encourages economic entities to introduce innovation, invest, develop international trade and human resources, and all this leads to the increase in productivity, economic growth, national competitiveness, lower prices and better business conditions.

Referring to the fact that the operational environment of Lithuanian and Latvian competition policy and the results of the quantitative research are similar, only one country Lithuania - has been selected for qualitative research, and based on its results, conclusions on the specifics of countries with a developing culture of competition were drawn. Qualitative research has shown that competition policy pursued in Lithuania is becoming more and more known, and $88 \%$ of respondents are aware of the goals and peculiarities of this policy. All the respondents surveyed support fair competition in the market and $93 \%$ of them believe that it is a prerequisite for maintaining a sustainable economy. The main reasons that encourage distortions of competition in the market, that were indicated by the respondents, include the pursuit of higher profits (86\%), a way to remain on the market $(72 \%)$, elimination of competition in the market and the increase of market power $(71 \%)$, reduction of costs in the competition market $(51 \%)$, implementation of joint activities (38\%), creation of barriers to entry to the market (22\%), search for information (8\%). $16 \%$ of the respondents indicated that the distortion of competition is encouraged by the fact that part of competitors on the market breach competition. $12 \%$ of the respondents referred to specific market conditions, $9 \%$ - unintentional actions. In general, in countries with a developing culture of competition a vast majority of economic entities, if they had intentions to breach competition in the market, would do so on a motivated basis and purposefully, rather than due to ignorance of the law.

$81 \%$ of the respondents are aware of the principles and diversity of sanctions for the breach of competition. This shows that in Lithuania more and more economic entities 
are familiar with competition policy. The results of the survey do not diminish the relevance of the competition culture distribution, as the survey results might have been improved by the fact that the survey participants were more or less engaged in the work related to competition policy.

The key sanction for deterrence from violations is a financial penalty imposed on an economic entity. This was mentioned by $91 \%$ of respondents. The individual manager's responsibility to pay a fine was indicated by 73 $\%$ of respondents. Publicity and the loss of reputation were indicated by $54 \%$ of respondents. This justifies the fact that the dissemination of information on the cases of disclosure of particular breaches would be a much more effective preventive measure than, for example, a general overview of the competition law regulations. $23 \%$ of respondents considered the elimination from the public procurement procedures as an important factor, especially those whose high proportion of revenues is related to public procurement. Less deterrent sanctions include claims for damages $(26 \%)$, prohibition of leadership (individual liability) (24 \%), amnesty programs (24\%) and imprisonment (individual liability) (11 \%). Such a distribution of sanctions by deterrence can be explained by the lack of practical application and insufficient awareness of these sanctions ${ }^{1}$, which gives economic entities a reason to believe that the probability of being captured and punished is not very high.

The conducted study revealed that the disclosure of any breach of competition law in Lithuania has a positive impact on the development of competition culture and reduces incentives to breach. $62 \%$ of the respondents indicated that if breaches of competition law were detected and their participants in the market of a relevant economic operator were punished, this would have a highly significant effect on the economic entity's staff's attitude towards competition as a value (the fact itself would remind and encourage considerations on competition as a value). The remaining part of respondents indicated a strong (24\%) or moderate $(8 \%)$ impact. $6 \%$ of respondents believe that the identified case would have no effect. $74 \%$ of respondents supported the statement that if the breach of competition law were detected and its participants in the market of a relevant economic operator were punished, this would deter from future violations of competition. $26 \%$ of respondents were categorical and argued that the disclosure and punishment for breaches of competition law would not deterred from intentions to generate higher profits or pursue other objectives.

Summarizing the research results, it is possible to maintain that in countries with a developing culture of competition, there is a positive tendency related to the fact that more and more economic entities support fair competition and consider competition itself as a value. In addition, although the identified deterrence from breaches of competition law in countries with a developing competition culture is lower than in the countries with a developed culture of competition, the impact of an effective competition policy for the reduction and discouraging incentives to violate competition is apparent.

\section{Conclusions}

The specifics of the impact of competition policy on the economy of a country with a developing culture of competition, as well as the methodological aspects of this assessment reviewed in this article, reflect an increasing global scientists', politicians' and entrepreneurs' interest in this issue and justify the relevance, timeliness and scientific novelty of the issues considered in Lithuania and Latvia.

The researches and results obtained in the article are treated as a significant contribution to the formation of an effective competition policy in the country with a developing culture of competition. The outlined areas of the manifestation of the impact of competition policy (reason), indicators reflecting the impact of competition policy (consequence), the results of the survey, clarify the methodology of assessing the impact of competition policy on the national economy of a country with a developing culture of competition and facilitates its practical use.

Measuring the impact of competition policy on the economy is a complex process, as it involves both direct and indirect (deterrence) effects. Analysis of the relationship between competition policy and economy, the impact on economy caused by breaches of competition (frequently damage), as well as the effect of sanctions for violations of competition enables to assess the manifestation of the impact of competition policy on economy.

The evaluation of competition supervisory authorities' activities according to the indicators of the government's appropriations and the direct and indirect benefit ratio is not sufficient enough when assessing the impact of competition policy on the overall economy of the country. It is important to analyse not only the aspects of competition supervision authorities and competition policy development (implementation), but also the economic entities' attitudes towards the existing competition policy and the cause effect chain of the impact of competition policy.

Theoretical and empirical studies have shown that there is a strong positive relationship between the effectiveness of competition policy and economic growth in the countries of a developed and emerging competition culture.

In countries with a developing competition culture, competition policy is mostly manifested through the same areas as in the countries with a developed competition culture: innovation, investment, international trade and human resources, i.e., by ensuring competition in the market, economic entities are encouraged to invest, develop international trade and human resources, and all this leads to the increase in productivity, economic growth, national competitiveness, lower prices and improvement of business conditions.

It is acknowledged that the deterrence of sanctions for violations of competition is difficult to assess. There is none universally recognized and the most effective tool for deterrence: all are suitable to apply if they contribute to the deterrence of violations of competition. Different tools complement each other and the use of different measures increases the deterrence.

Financial sanctions remain among the most important and most deterrent tools from violations of competition law in the countries with a developing culture of competition. 
Irena Pekarskiene, Jurgita Bruneckiene, Rasa Daugeliene, Lina Peleckiene. The Impact of Competition Policy on the...

Practical implementation of the sanctions for violations of competition, dissemination of information to the public, strengthening the public and private enforcement of competition law, protection of collective rights, raising the overall level of competition culture and strengthening of organizations that protect consumer rights is becoming an essential prerequisite for ensuring the deterrence of sanctions for violations of competition.

\section{References}

Aydin, U. (2012). Promoting Competition: European Union and the Global Competition Order. Journal of European Integration, 34(6), 663-681. https://doi.org/10.1080/07036337.2012.707366

Baker, J. B. (2003). The Case for Antitrust Enforcement. Journal of Economic Perspectives, 17, 27-50. https://doi: $10.1257 / 089533003772034880$

Bertrand, O., \& Ivaldi, M. (2006). European competition policy in international markets. IDEI Working Paper, 419. https://doi.org/10.2139/ssrn.951594

Bolotova, Y., Connor, J. M., \& Miller, D. J. (2008). Factors influencing the magnitude of cartel overcharges: An empirical analysis of the US Market. Journal of Competition Law and Economics, 5(2), 361-381. https://doi.org/10.1093/joclec/nhn025

Borrell, J. R., \& Tolosa, M. (2008). Endogenous antitrust: cross-country evidence on the impact of competition-enhancing policies on productivity. Applied Economics Letters, 15(11), 827-831. https://doi.org/10.1080/13504850600949137

Bruneckiene, J., \& Pekarskiene, I. (2015). Economic efficiency of fines imposed on cartels. Inzinerine EkonomikaEngineering Economics, 26(1), 49-60. https://doi.org/10.5755/j01.ee.26.1.7763

Bruneckiene, J., Pekarskiene, I., Guzavicius, A., Palekiene, O., \& Soviene, J. (2015). The Impact of Cartels on National Economy and Competitiveness: A Lithuanian Case Study. Springer. https://doi.org/10.1007/978-3-319-17287-3

Buccirossi, P. Ciari, L., Duso, T., Spagnolo, G., \& Vitale, C. (2011). Measuring the deterrence properties of competition policy: The Competition Policy indexes. Journal of Competition Law \& Economics, 7(1), $165-204$. https://doi.org/10.1093/joclec/nhq021

Buccirossi, P., Ciari L., Duso, T., Spagnolo, G., \& Vitale C. (2013). Competition Policy and Productivity Growth: An Empirical Assessment. The Review of Economics and Statistics, 95(4), 1324-1336. https://doi.org/10.116 2/REST_a_00304

Chang, M. H., \& Harrington, J. E. (2010). The impact of a corporateleniency program on antitrust enforcement and cartelization. Available from internet: http://www.econ.jhu.edu/pdf/papers/wp548.pdf

Clougherty, J. A. (2010). Competition Policy Trends and Economic Growth: Cross National Empirical Evidence. International Journal of the Economics of Business, 17(1), 111-127. https://doi.org/10.1080/13571510903516995

Competition Council of Latvia (2017). Available from internet: http://www.kp.gov.lv/en/annual-reports

Connor, J., \& M. (2008). Global Antitrust Prosecutions of International Cartels: Focus on Asia. https://doi.org/10.2 139/ssrn. 1027949

Connor, J., \& Lande, R. (2007). Cartel Overcharges and Optimal Cartel Fines. https://doi.org/10.2139/ssrn.1285455

DePamphilis, D. M. (2014). Mergers, acquisitions, and other restructuring activities an integrated approach to process, tools, cases, and solutions. Academic Press. JAV, San Diego.

Doytch, N., \& Uctum, M. (2011). Sectoral growth effects of cross-border Mergers and Acquisitions. Eastern Economic Journal. 38(3), 319-330. https://doi.org/10.1057/eej.2011.16

Doytch, N., \& Cakan, E. (2011). Growth effects of mergers and acquisitions: a sector-level study of OECD countries. Journal of Applied Economics and Business Research, 1(3), 120-129. Available from internet: https://pdfs.semanticscholar.org/ 9ab8/16f5a59972e7078fe5759c663cd66c64a2f5.pdf.

Dutz, M. A., \& Hayri, A. (1999). Does more Intense Competition Lead to Higher Growth? (Vol. 2249). World Bank Publications. Available from internet: http://documents.worldbank.org/curated/en/419001468739337795/pdf/multipage.pdf. https://doi.org/10.1596/1813-9450-2320

Dutz, M. A., \& Vagliasindi, M. (2000). Competition policy implementation in transition economies: an empirical assessment. European Economic Review, 44, 762-772https://doi.org/10.1016/S0014-2921(99)00060-4

Eekhoff, J., \& Moch, C. (2004). Competition - the core of a market economy. Competition Policy in Europe. (p.p 1-28). https://doi.org/10.1007/978-3-540-24712-8 
European Commission (2016). Why we need a European competition policy. Available from internet: http://ec.europa.eu/competition/publications/kd0216250enn.pdf.

European Commission (2017). Looking beyond the direct effects of the work of competition authorities: deterrence and macroeconomic impact. ec.europa.eu/competition/information/.../invitation_en.pdf.

Ginevicius, R., \& Krivka, A. (2009). Multicriteria evaluation of the competitive environment in the oligopolic market. Business: Theory and Practice, 10, 247.

Global Competition Review (2015). Rating Enforcement thE Annual Ranking of the World's Leading Competition Authorities. Volume 18 (6).

Grout P. A., \& Sonderegger S. (2005). Predicting cartels. Economic discussion paper. 773 OFT. Available from internet: http://www.oft.gov.uk/shared_oft/reports/comp_policy/oft773.pdf

Gunster, A., Carree, M., \& van Dijk, M. A. (2011). Do Cartels Undermine Economic Efficiency? Available from internet: http://druid8.sit.aau.dk/acc_papers/r562i7151f7hp9rv11dnahc0spep.pdf.

Gutmann, J., \& Voigt, S. (2014). Lending a Hand to the Invisible Hand? Assessing the Effects of Newly Enacted Competition Laws.

Hinloopen, J., \& Normann, H. T. (2009). Experiments and Competition Policy. Cambridge University Press. https://doi.org/10.1017/CBO9780511576201

Huschelrath, K. (2009). Detection of anticompetitive horizontal mergers. Competition Law \& Economics, 5(4), 683-721. https://doi.org/10.1093/joclec/nhp008

Huschelrath, K., \& Weigand, J. (2010). Fighting Hard Core Cartels. Available from internet: https://doi.org/10.21 39/ssrn.1727396

Jones, A., \& Sufrin, B. (2004). EC Competition Law, 2nd edn., Oxford University Press.

Khimich, A., Ivaldi, M., \& Jenny, F. (2011). Measuring the Economic Effects of Cartels in Developing Countries. Available from internet: http://unctad.org/en/Pages/DITC/CompetitionLaw/ResearchPartnership/MeasuringCartels.aspx.

Klimasauskiene, D. (2006). Konkurencijos politika: teorija ir praktikos aktualijos. Available from internet: http://web.ebscohost.com/bsi/detail?vid=3\&hid=16\&sid=d555f0e5-fefc-4f19-bdfaa741d5a73010\%40sessionmgr7

Lande, R., \& Davis, J. (2008). Benefits from Private Antitrust Enforcement: An Analysis of Forty Cases. University of San Francisco Law Review 42, 879-918.

Lande, R. H., \& Connor, J. M. (2005). How High Do Cartels Raise Prices? Implications for Reform of the Antitrust Sentencing Guidelines. Available from internet: https://doi.org/10.2139/ssrn.787907

Levenstein, M. C., \& Suslow, V. Y. (2004). Contemporary international cartels and Developing countries: economic effects and implications for competition policy. Antitrust Law Journal, 71 (3), 801-852. Available from internet: http://www-personal.umich.edu/ maggiel/ALJ.pdf.

Lietuvos Respublikos Konkurencijos taryba. (2017). Available from internet: http://kt.gov.lt/

Lietuvos statistikos departamentas (2017). Available from internet: http://www.stat.gov.lt.

London Economics. (2011). The Nature and Impact of Hardcore Cartels. London Economics - Competition Economics. Available from internet: http://www.londecon.co.uk/publication/the-nature-and-impact-of-hardcore-cartels.

Ma, T. C. (2011). The effect of competition law enforcement on economic growth. Journal of Competition Law and Economics, 7(2), 301-334. https://doi.org/10.1093/joclec/nhq032

Mackenrodt, M. O., \& Gallego, B. C. (2008). Abuse of dominant position: new interpretation, new enforcement mechanisms? S. Enchelmaier (Ed.). Springer. https://doi.org/10.1007/978-3-540-69965-1

Maier-Rigaud, F., \& Schwalbe, U. (2013). Quantification of antitrust damages. Competition Damages Actions in the EU: Law and Practice. Edward Elgar. Available from internet: https://doi.org/10.4337/9781782540762.00017

Manyika, J., Woetzel, J., Dobbs, R., Remes, J., Labaye, E., \& Jordan, A. (2015). Global growth: Can productivity save the day in an aging world. New York: McKinsey Global Institute. Available from internet: http://MGI_Global_growth_Full_report_February_2015pdf\%20(3).pdf

Marshall, R. C., \& Marx, L. M. (2012). The economics of collusion: Cartels and bidding rings. Mit Press.

McKinsey Global Institute (2015) Global growth: Can productivity save the day in an aging world? 
Irena Pekarskiene, Jurgita Bruneckiene, Rasa Daugeliene, Lina Peleckiene. The Impact of Competition Policy on the ...

Miller, N. (2009). Strategic Leniency and Cartel Enforcement. American Economic Review 99, 750-768. https://doi.org/10.1257/aer.99.3.750

Mosteanu, T., \& Romano, O. M. (2013). Competition Policy and the Economic Crisis. European Union Case Study. Procedia Economics and Finance, 6, 662-667. https://doi.org/10.1016/S2212-5671(13)00186-X

Motta, M. (2007). Competition Policy. Theory and Practice. New York: Cambridge University Press.

Nickell, S. J. (1996). Competition and Corporate Performance. Journal of Political Economy, 104(4), 724-746. https://doi.org/10.1086/262040

Novosad, A., \& Moisejevas, R. (2012). Novelties of Method of Setting Fines imposed for Infringements of Lithuanian Law on Competition. Jurisprudence 2012, 19(2), pp. 625-642. Available from internet: http://socin.mruni.eu/wpcontent/uploads/2012/12/A_2012-12-261.pdf\#page=176.

OFT (2007). The Deterrent effect of competition enforcement by the OFT, OFT962 Available from internet: www.oft.gov.uk/shared_oft/reports/Evaluating-OFTs-work/oft962.pdf

Pekarskiene, I., \& Bruneckiene, J. (2015). The relationship between cartels and economic fluctuations. Inzinerine Ekonomika-Engineering Economics, 26(3), 284-294. https://doi.org/10.5755/j01.ee.26.3.7331

Petersen, N. (2013). Antitrust Law and the Promotion of Democracy and Economic Growth. Journal of Competition Law \& Economics, 9 (3), 593-636. https://doi.org/10.1093/joclec/nht003

Porter, M. E. (2000). The Competitive Advantage of Notions. Harvard business review.

Qaqaya, H., \& Lipimile, G. (2008). The effects of anti-competitive business practices on developing countries and their development prospects. Available from internet: http://unctad.org/en/Docs/ditcclp20082_en.pdf

Rodger, B. (2005). Law Compliance Programs: A Study of Motivations and Practice, World Competition 28, 349-376.

Romano, O. (2015). Assessing the Macroeconomic Effects of Competition Policy - the Impact on Economic Growth. Economic Insights - Trends and Challenges. 3, 81-88. Available from internet: http://www.upg-bulletinse.ro/archive/2015-3/9.Romano.pdf.

Sama, D. (2013). The Effectiveness of Competition Policy: An Econometric Assessment in Developed and Developing Countries. https://doi.org/10.2139/ssrn.787907

Stanikunas, R. (2009). Konkurencijos politika: teorija ir praktika. Vilnius: TEV.

Utton, M. A. (2011). Cartels and economic collusion: The persistence of corporate conspiracies. Edward Elgar Publishing. https://doi.org/10.4337/9781849807715

Van Bergeijk, P. A. G. (2010). What could anti-trust in the OECD do for development?. ISS Working Paper Series / General Series , 473, 1-19. Erasmus University Rotterdam. Retrieved from http://hdl.handle.net/1765/18290

Werden, G. J. (2003). The 1982 merger guidelines and the ascent of the hypothetical monopolist paradigm. Antitrust Law Journal, 71(1), 253-275.

The article has been reviewed.

Received in August, 2017; accepted in February, 2018. 